\title{
Pre-Service Teachers’ Understandings of Literacy Practices
}

\author{
Avis M Masuda ${ }^{1, *} \&$ Michele M Ebersole ${ }^{1}$ \\ ${ }^{1}$ School of Education, University of Hawaii at Hilo, Hilo, HI 96720-6214, USA \\ *Corresponding author: School of Education, University of Hawaii at Hilo, Hilo, HI 96720-6214, USA \\ Tel: 1-808-933-1162 E-mail: ammasuda@hawaii.edu
}

Received: July 1, 2013

doi:10.5430/jct.v2n2p47
Accepted: August 12, $2013 \quad$ Online Published: September 4, 2013

URL: http://dx.doi.org/10.5430/jct.v2n2p47

\begin{abstract}
This paper presents a 2-year study of pre-service teachers' understandings of and views toward literacy. Data were collected via pre-service teachers' 48-hour literacy log, reflections and lesson plans. Findings indicate that pre-service teachers' perceptions of literacy were initially bound by traditional views toward literacy, focusing solely on print based literacy. Throughout the semester via coursework and field experience, pre-service teachers gained new insights about the literacies of their students. By the end of the semester they had broadened their understandings of and views toward literacy, acknowledging the need to support their students' academic literacy and they affirmed the need to learn how to engage in instructional practices that support twenty-first century skills in order to bridge the gap between their students' life-world and academic literacy. However, upon transition into field experiences they encountered several barriers such as limited accessibility and school policies precluded use of their newfound conceptions in their teaching. The significance of the study puts forth an implication for teacher educators to support pre-service teachers with opportunities to explore and ground their professional beliefs about literacy and opportunities to engage as reflective practitioners.
\end{abstract}

Keywords: pre-service teachers; literacy perspectives; teacher education

\section{Introduction}

Pre-service teachers' understandings of literacy is situated and located within particular times, spaces, and discourses (Barton, Hamilton, \& Ivanic, 2000). Their perceptions of what counts as literacy can influence the pedagogy and curriculum in which they engage their students. These perceptions may also create a disjuncture with the multiple literacies that their K-12 students bring to the classroom. The twenty-first century demands that a literate person possess a wide range of abilities and competencies as well as employ multiple literacies across contexts of school, work and community (National Governors Association Center for Best Practices \& Council of Chief State School Officers, 2010).

The purpose of this study is to investigate pre-service teachers' perceptions of literacy and how these understandings shift over the course of their teacher education program. To guide our study, we engaged in a self-inquiry into our teacher preparation literacy courses and explored the following questions:

1. What are pre-service teachers' initial understandings of literacy?

2. What understandings of literacy emerge during their coursework?

3. What happened to their understandings of literacy once they transitioned into their field classrooms?

\section{Relevant Scholarship}

\subsection{What's Valued: Literacy Practices}

Twenty-first century literacy skills require that students have multiple forms of knowledge and understandings about literacy and social contexts that enable appropriate and successful performance in all aspects of life (Anstey \& Bull, 2006; National Governors Association Center for Best Practices \& Council of Chief State School Officers, 2010). With changing times comes changing literacies and literate practices today are influenced by the increasing 
complexity and diversity of texts and technologies, implicating change for literacy education.

Exemplary literacy instruction takes into account students' personal and everyday literacies to engage them in academic tasks (Alvermann, 2001). Academic literacies often focus on student achievement of discrete skills. However, teachers need to recognize that students conduct literacy-related practices in their everyday lives, both inand out-of-school (Hull \& Schultz, 2001; Larson \& Marsh, 2005). When teachers identify the literate practices of their students and the social and cultural influences on their literate practices, they work towards ensuring teaching and learning activities are relevant, meaningful to students, and acknowledge their diversity (Anstey \& Bull, 2006). Therefore, teacher preparation programs need to support pre-service teachers by giving them opportunities to explore different conceptions of literacy so that their practices are not located solely in a focus on discrete skills (Larson \& Marsh, 2005; Street, 1995), but are able to meet the demands of a changing world.

\subsection{What's Expected of Teacher Education}

Teacher education programs are bound by national accreditation standards for preparation of pre-service teachers. Programs are evaluated for pre-service teacher pedagogical content knowledge and skill preparation, along with critical dispositions. Within such pedagogical content knowledge, it can be inferred that the expectation that pre-service teachers will meet performance skills such as, "The teacher uses a variety of instructional strategies to support and expand learners' communication through speaking, listening, reading, writing, and other modes” (Council of Chief State School Officers, 2011) in order to foster their students' literacy development.

Currently, forty-five states have adopted the Common Core State Standards (National Governors Association Center for Best Practices \& Council of Chief State School Officers, 2010). The Standards also "lay out a vision of what it means to be a literate person in the twenty-first century" (p.1). Literacy expectations have increased in rigor in order to better prepare our students with college and career readiness skills. As put forth in the Common Core Standards, students must demonstrate independence, build strong content knowledge, respond to the varying demands of audience, task, purpose, and discipline, comprehend as well as critique, value evidence, use technology and digital media strategically and capably, and understand other perspectives and cultures.

While well intended, these standards bias academic standards for literacy often emphasizing "instructional strategies" and cognitive skills rather than nurture the development of multiple forms of knowledge and understandings of literacy. Thus, teacher educators are often caught between what's valued such as exploring different conceptions of literacy and what's expected in teacher preparation (constraints imposed by external agencies) within locally situated contexts.

\section{Method}

\subsection{Research Context}

The study took place in a rural island community at an institute of higher education with approximately 4,000 undergraduate students, serving an ethnically diverse population. Almost half of the student population represented Asian or Pacific Islanders. The teacher preparation program was a post-baccalaureate program, which recommended approximately 35 candidates for a teaching license each year. The program utilized a cohort model, which enabled full-time students to complete both instructional and field components in one academic year.

\subsection{Participants}

A qualitative approach was used to explore pre-service teachers' conceptions of literacy. Convenience sampling was used with elementary and secondary pre-service teachers during the first semester of their teacher education program. Data were collected for the elementary cohort by one of the authors who taught an integrated language arts and social studies methods course. For the secondary cohort, data were collected in a content area literacy course taught by the other author. Although the content and purpose of the courses differed, the philosophical framework toward literacy was closely aligned. Several common engagements were experienced by both groups of pre-service teachers Two years of data were collected on two different groups of pre-service teachers (elementary and secondary); 30 participated in the first year and 40 participated in the second year. Two elementary cohort members and two secondary cohort members chose not to participate in the study in the first year; however, all cohort members elected to participate in the second year. In keeping with the parameters of the IRB, participants could opt out of the study at any time.

\subsection{Data Sources}

Based on the pre-service teachers' experiences the following data sources were collected: a 48-hour literacy log, three literacy reflections and one literacy lesson plan. These particular data sources were selected because the literacy log 
and literacy reflections captured the actual language used by these pre-service teachers and could be used to interpret their conceptions of literacy that prevailed over the course of the study could be examined. The lesson plan indicated how the pre-service teachers' views toward literacy might be reflected in their pedagogy. These data sources were analyzed to avoid an over-reliance on one particular source and to substantiate findings (Silverman, 2001).

\subsubsection{8-hour Literacy Log}

At the onset of both courses, pre-service teachers documented and logged all literacy and literacy related activities over a 2-day period to examine the role of literacy in their lives. Activities include reading and writing of texts (both print and digital). For example, an hourly record might look like:

7:00 - 8:00 am READ: nutrition label on cereal box; front page, sports section, comics, sale ads

Context: while eating breakfast

READ: $\quad$ Phone and address in phone book; Facebook page, emails, text

Context: Needed to contact peer for class assignment clarification

WROTE: Shopping list

Context: While organizing my to do list for day

WROTE: Text message to peer to meet up and email to instructor

Context: To get information and work on class assignment

\subsubsection{Literacy Reflections}

Reflections were encouraged as a means of enabling these pre-service teachers to share their thinking and reflect upon their learning. Three different literacy reflections were collected each year; one at the beginning of the semester, one at midpoint, and one at the end of the semester, after a 200 hour field experience. Varying prompts, constructed together by both researchers, were posed to reflect on their learning. For the initial reflection, these questions were asked: What did you learn about your own literacies? What does this mean for you as a future teacher? For the midpoint reflection, the pre-service teachers were asked: Revisit your generalization about literacy, and think about your views toward your students' literacies and practices. Please explain any changes in your thinking. Lastly, for their final reflection, they were asked to respond to: Have your initial thoughts about literacy changed in any way? Explain.

\subsubsection{Lesson Plans}

Lesson plans reflected the pre-service teachers' pedagogical views toward literacy. While both researchers were aligned in their philosophical stance toward literacy, and too reduce bias, both researchers collaborated and worked on specific lesson planning instruction and used the same components for the lesson plan: standard, objective, assessments, instructional procedures and timing (with opening, development, and closure), and modifications for diverse learners. We agreed on lesson due dates and used the same rubric for lesson plan evaluation. Some of the pre-service teachers were able to teach their lesson plans in their field experience; however, for others it served as a cognitive rehearsal to reflect ideas about literacy practices. Two literacy lesson plans were collected each year.

\subsection{Data Analysis}

Data were organized and labeled according to cohort group (Elementary Year 1 and Year 2; Secondary Year 1 and Year 2). Each participant was assigned a number as an identifier and the same number used on each data source. Data analysis was a continuous and recursive process. A thematic approach was used to look across all the data to identify the common issues that recur, and to identify the main themes that emerged relevant to the aims of the study. The researchers each read through the 48-hour literacy logs, three literacy reflections, and two lesson plans for each participant in their respective course and wrote notes in the margins. These notes helped to form preliminary observations to get a feel for the data. The pre-service teachers' literacy logs, literacy reflections and the lesson plans were then reviewed with multiple readings to look for words or phrases that possibly reflected emerging ideas about literacy practices. Possible categorical headings were noted next to the words/phrases in the margins so references to the context could be made at a later reading. Sometimes additional notes were written as possible connections. Each researcher then compared categorical headings for her respective cohort group across the two years, noting similarities or exceptions. To strengthen validity, both researchers then worked together and analyzed the elementary and secondary cohort data to confirm categorical headings. Using a constant comparison method (Glaser \& Strauss, 1967), common themes were identified with respect to these pre-service teachers' perceptions towards literacy across the two years. 


\section{Results}

\subsection{What were Pre-Service Teachers' Initial Understandings of Literacy?}

At the start of the semester, these pre-service teachers were asked to complete a literacy log of their literate activities for a 48-hour period (one school day, one at home day). Upon reflection on their own literacy practices, they all came to the conclusion that literacy practices are an integral part of daily life and their everyday practices. They acknowledged the multiple literacies used within different domains of their lives, home vs. school vs. work (Barton \& Hamilton, 2000). They generalized, "Literacy is essential to being able to survive and function in our globalized society." Literacy practices enabled social interaction. Literacy was not only a means to "gather and respond to information" but "connects us to the rest of humanity."

Several pre-service teachers concluded that literacy is a means through which we mediate the world around us, including the use of social and cultural knowledge. For example, one teacher shared that literacy can, "enable one to comprehend and demonstrate appropriate understanding of the social and cultural norms which allow humans to behave as functioning members in their individual cultural environments and societies.” The pre-service teachers reflected upon different types of social and cultural knowledge they needed to be active participants ("Even when I was at the beach, reading the sunscreen bottle and talking about fishing were both activities that involved literacy. I had to be literate in all of the fishing terms we were using in our discussion in order to be able to participate in the conversation"). In other words, they began to see that literate persons could read and negotiate multiple texts within different domains of their life (home, work, school).

Many admitted that they initially thought literacy was just "reading and writing," but in examining their practices, they realized literacy has many forms. The influence of technology was a key theme in shaping their everyday literacy practices. As the semester wore on, through coursework readings and discussions, these pre-service teachers broadened their perspectives toward literacy.

\subsection{What Understandings of Literacy Emerged During Their Coursework?}

The majority of the pre-service teachers acknowledged literacy was not merely "black and white" - reading and writing print texts. They learned that texts were not only paper-based, but also electronic and live (Anstey \& Bull, 2006). For example, they considered how they read different semiotic systems with digital media as well as used their discursive knowledge of social and cultural experiences to read social contexts. Literacy was more than reading and writing for school; they recognized their K-12 students conducted literacy-related practices outside of school, largely due to the influence of digital media. Many of their students were far more tech-savvy than themselves; they were often "plugged in." They understood that their students were motivated by and more attentive when technology was used in literacy practices within the school-based world of teaching and learning. They also found that many of their students "enjoyed reading" especially when they "chose what to read" and that they "read for pleasure or recreation." The pre-service teachers theorized about teaching practices that they felt would support these new understandings.

Many reflected that it was important to find balance in teaching to help develop students as literate persons by bridging school-based world and life-world literacies:

Literacy is not just a school activity, and we mustn't forget that literacy is evolving. Therefore, our school-based world, which includes all pedagogical activities, all disciplines, all text-based activities and mediation of text, must too evolve. We must be open to life-world literacy, which includes all social and cultural experiences and self-directed recreational activities. It needs to be welcomed into the classroom and made a part of the students' learning experience. Students can learn so much more by bringing in their real-life experiences and connecting their life to learning. If there is no connection between school and real life, then it makes the experience in the classroom meaningless.

By incorporating real-life experiences and valuing the experiences that students bring with them they felt it would "teach students to appreciate literacy" and "develop a sense of who they are as literate people."

Nearly all of the pre-service teachers noted they would incorporate the use of technology in teaching. They recognized their students' receptiveness to learning with technology as a strength that could support their learning, as indicated by this pre-service teacher:

I feel that it is imperative the students have the opportunity to learn how to use this technology to enrich their literacy and manage their modern lives effectively, safely, and ethically. Not only that, but the potential to enrich lessons with fast, engaging forms of media and information are an exciting possibility to teachers; since a high number of students may be visual learners, the right addition of display technology in the classroom can really enhance students' 
grasp of new concepts, or strengthen mastery of existing ones. Most students are already more predisposed to multimedia and online content than 'traditional' texts and classroom materials. The interactive nature of today's technology is also strength: it allows for a personalized kind of cooperative learning, even when the student using it is working independently.

Some pre-service teachers considered the possible use of blogs, wikis, podcasting, video production, or even considered the cell phone as teaching tool since "nearly every student has one." As they started to acknowledge the multiple texts that could be accessed because of technology within our everyday lives, another common idea voiced was the importance of not only teaching students to use technologically effectively and ethically, but to teach them to use critical literacy practices to examine texts ("use my literate practices not to be cheated in today's society" or "students need to be able to discern quality information from misinformation").

One secondary student justified his use of current events in his social studies unit, "Incorporating current events helps students become critical analysts of texts, as news media is one of the best ways for students to become aware of inherent biases in texts." Yet, in contrast, he critically noted, "appropriating time for current event studies thus comes at an expense of the information that I am accountable to teach my students." Here, he implies that they were held accountable to teaching to particular history content benchmarks, which did not directly link to current events.

At this point in the semester, it appeared that some of these pre-service teachers began to recognize and broaden their conceptions of literacy and literacy practices. As they prepared to transition into their field classrooms, we noticed their views shifted again.

\subsection{What Happened to Their Understandings of Literacy Once They Transitioned into Their Field Classrooms?}

As they spent more time in their field classrooms, the pre-service teachers began to draw upon their knowledge of school-based literacies or the academic literacies K-12 students needed to complete academic tasks. While they still recognized the strong influence of technology in their students' lives, written reflections focused on concerns with their students' lack of proficiency with academic skills. Often, the lesson plans for secondary pre-service teachers' coursework centered on content literacy strategies, vocabulary instruction, note taking, or the use of graphic organizers. For elementary pre-service teachers, predicting, identifying expository text features, introducing text structures, comparing/contrasting characterized their initial lessons.

Within their lesson plans, secondary pre-service teachers incorporated the use of technology as teaching tools; primarily PowerPoint lectures or short video clips. In contrast, when they reflected upon their earlier views prior to working with their students, they lamented how their intended lessons had changed because of the following barriers, which precluded them from attempting lessons that might bridge their students' multiple literacies.

\subsubsection{Barriers}

After returning from their student teaching practicum, several of the teachers compared their "idealistic" plans for using technology with their teaching to the realities of day-to-day teaching. One of the primary reasons cited was the lack of resources or the "lack of realistic availability of student access to computers." Additionally, technology in schools was unreliable. One pre-service teacher stated, "The classroom of my cooperating teacher does not have a projector for the computer. There is a stand for it, it is supposed to be there, but hasn't been for two years. Other teachers in the department have broken ones, and few seem to work.”

School policies also posed a challenge for some of the pre-service teachers, where policies "prohibit all users of school Internet from accessing that particular site" and teachers were asked to adhere to these policies ("As a new and incoming teacher, implementing an instructional practice that goes against school policy would be ill-advised and should not be done under any circumstance.” Most of the schools prohibited access to YouTube and several blogging sites. For others, they saw the constraints posed by the schools and noted their own need to familiarize and update their technology skills in order to effectively incorporate technology within their lessons.

Lack of time was attributed as another barrier to implementing lessons that bridged students' in- and out-of-school literacies through technology. These pre-service teachers felt they had to follow curriculum-pacing calendars and had to teach "many standards that need to be addressed in such a small amount of time." Like the pre-service teacher who felt the pressure of accountability in taking time to teach current events, another teacher noted, "We are bound by the standards to teach our students mostly in terms of traditional literacy, because they are tested on it."

Oftentimes, elementary pre-service teachers were bound by reading programs that "focus more on conventions, phonemic awareness, phonics, and vocabulary in a repetitive manner which helps students learn to read; however, school systems don't ever focus on 'real' life situations where students can make connections.” 
Despite these barriers, most of these pre-service teachers maintained a positive outlook and still recognized the importance of preparing students to be multiliterate.

\subsubsection{Remaining Positive}

Several of the pre-service teachers reflected upon the importance of helping students see real world connections in their teaching and still believed they should embrace students' cultural backgrounds, evidenced by their reflections that "students learn best when they can relate to what they are learning" and "I believe in incorporating a sense of place and cultural relevancy, given where we live."

These pre-service teachers still saw the need for supporting both academic and in their life-world, outside of school literacies: "Students need to use both social and academic literacies to be an active and engaged citizen in the world .. . By having the ability to be socially literate, students can participate in a society that is technologically driven." Two teachers still pondered the use of cell phones as an instructional tool that might support students' literacy development; one considered exploring the permitted use of cell phones to help students stay focused by texting homework assignments or homework reminders; or, sending reminders to students and parents about upcoming projects or school events. In his words, "these are only a few drops in the proverbial ocean of possible content” that can support technological literacy in the classroom.” In these pre-service teacher candidates' teaching contexts, their emerging views toward literacy and their corresponding teaching practices were disrupted by what they perceived as barriers or performance expectations.

In sum, pre-service teachers' initial perceptions of literacy were bound by traditional views toward literacy being defined as reading and writing, focusing solely on print based or academic literacy. Throughout their coursework, they maintained a stance about the significant role that technology plays in our world and their students' lives. Prior to their field experience, they gleaned new insights into teaching practices that included both in-school and out-of-school literacies. After time in their field classrooms, these pre-service teachers understood that while both can reside within the school context, there are often barriers that preclude the implementation of practices which bridge literacies in students' life-world and academic literacy demands of the school-based world (Anstey \& Bull, 2006).

\section{Discussion}

Barton (2000) suggested that helping students explore ideas about literacy is strongly supported by their examination of their own literate practices in the everyday world. The pre-service teachers' literacy log and reflections throughout their coursework and field experience helped them to expand their thinking and beliefs about literate practices. At the same time, being immersed within the context of teaching, there was an imminent focus on academic literacies, student achievement, state assessments, and accompanying accountability discourses.

These pre-service teachers recognized the various literacies that are practiced according to the different domains of activity-home vs. school or work vs. school; their own examination of literacy practices helped them to see how their literacies are used to function/survive across different types of social interactions and discourse communities. The influence of technology remains paramount in our contemporary society and being able to function as well as socially participate requires knowledge of different media and symbolic systems within different domains. The pre-service teachers realized that it was important to be proficient in academic literacies and those that help students negotiate their life-worlds.

Education is a socially powerful institution and school-based literacies tend to be the more dominant, visible, and influential. The pre-service teachers were held to expectations of incorporating state standards within their lesson plans to get their students ready for state tests, staying on schedule with pacing guides, meeting teacher performance standards, etc. as part of their being able to successfully pass and complete their student teaching practicum.

These pre-service teachers saw literacy practices as a means to some end. They discovered that their multiple literacies were integral to their daily lives-reading traffic signs, getting information, communicating, completing homework, interacting with others, etc. In teaching within their field classrooms, they found that literacy served as a community resource for social groups. Students' use of text messaging social networking, and email were part of a social communication medium that represented acceptance into being part of a connected discourse community.

Within these changing times and changing literacies, literacy can be viewed as fluid, dynamic, and continually evolving with rapidly changing technologies. Many of these pre-service teachers acknowledged their own struggle with being digital immigrants vs. digital natives, like the students in their classrooms. Within the school context, teachers are subjected to intense levels of accountability, posing tension for bridging school world and life-world 
literacies.

Overall, these pre-service teachers wrestled with their understandings and were just beginning to theorize their beliefs about literacy and how these might guide their actions and pedagogy. For example, one pre-service teacher indicated, "In addition to traditional literacies, I must take advantage of every opportunity to bolster social, ethical, and cultural literacies, for even the most academically adroit student will flounder in the real world without them.” They affirmed the importance of cultivating academic literacy, while at the same time saw a need for teachers to learn more effective ways of supporting their students' literacy development in an increasingly complex world.

\section{Implications for Teacher Education}

These pre-service teachers broadened their understanding of literacy as social practices and began to discover the complexities of the dominant school-based literacies that influence teaching practices. Through meaningful engagement within the broader social and cultural practices, they discussed ways they could purposefully enhance traditional literacy learning. Although the study is limited to these pre-service teachers' reflections upon literate practices and inferences drawn upon their lesson plans, the significance of the findings puts forth an implication for teacher educators to support pre-service teachers with opportunities to explore professional beliefs about literacy.

Our study is significant because it addresses a real issue for teacher educators. We fall prey to the same pressures and external demands of teacher preparation. We try to prepare teacher candidates with a broad array of professional knowledge and skills within a short duration; in doing so, we neglect the critical dispositional stance of grounding them as reflective practitioners (Schon, 1984).

As we reflected upon our findings, these pre-service teachers started to articulate their beliefs about literacy; at the onset of our courses, they shared their initial beliefs about literacy. As the course progressed and they read about various theoretical perspectives about literacy, they articulated their expanded views toward literacy. However, once they transitioned into their field experiences, their actual practice as drawn from their lesson plans sometimes contradicted their articulated beliefs.

This points to an implication for us as teacher educators, as well as limitations in our study: we did not uncover these pre-service teachers' thinking behind their instructional decisions/actions. As we look back upon the reflections, we realized our prompts were very broad - it prompted their personal ideas, as opposed to having them reflect upon their instructional practice and how it connects to or is grounded in their beliefs. We also did not disaggregate the data by demographic data to see if similarities or differences in pre-service teachers' thinking occurred across these variables.

Perhaps these pre-service teachers were still in a 'developmental stage' of establishing beliefs about literacy. Once in their field contexts, they are caught up in tasks of learning how to teach; they feel pressure to perform and implement school-based views of literacy, which are imposed by accountability demands. Thus, in order to transform literacy teaching practices and knowledge about literacy, pre-service teachers will need scaffolding and support to learn and grow. We continue to refine our educator preparation courses; additional areas for research could examine how we might incorporate tools to strengthen their praxis as reflective practitioners. For example, we could have pre-service teachers annotate lesson plans that help anchor their thinking in theoretical perspectives to help them make sound instructional decisions to support their students' literacy development. If pre-service teachers have opportunities to engage as reflective practitioners (Schon, 1984) - it gives them the language and tools to be self-reflective and self-reflexive. Action should not come without reflection for when we act without reflection, we act on other's purposes (Dewey, 1938).

As they grow as professionals they may encounter varying perspectives towards literacy. Helping prospective teachers form early understandings about literacy during their pre-service preparation will provide a filter for making sense of the knowledge and experiences they will encounter in their teaching careers (Feiman-Nemser, 2001). Taking up a stance, as a reflective practitioner, will help them continue to understand how their instructional decisions/practices support their students' literacy development, whether it is the school-based views of literacy or other perspectives they might glean with time and professional knowledge. They can analyze, question and make informed decisions, which in the long run, will benefit their students. 


\section{References}

Alvermann, D.E. (2001, December). Effective literacy instruction for adolescents. Executive Summary and Paper Commissioned by the National Reading Conference. Chicago, IL: National Reading Conference.

Anstey, M., \& Bull, G. (2006). Teaching and learning multiliteracies: Changing times, changing literacies. Newark: International Reading Association.

Barton, D. (2000). "Researching literacy practices: Learning from activities with teachers and students,” In D. Barton, M. Hamilton, \& R. Ivanic (Eds). Situated literacies: Reading and writing in context, pp. 167-79. London: Routledge.

Barton, D., \& Hamilton, M. (2000). “Literacy practices,” In D. Barton, M. Hamilton, \& R. Ivanic (Eds). Situated literacies: Reading and writing in context, pp. 7-15. London: Routledge.

Barton, D., Hamilton, M., \& Ivanic, R. (Eds.). (2000). Situated literacies: Reading and writing in context. London: Routledge.

Council of Chief State School Officers. (2011, April). Interstate Teacher Assessment and Support Consortium (InTASC) Model Core Teaching Standards: A Resource for State Dialogue. Washington, DC: Author.

Dewey, J. (1938). Experience and education. New York: Touchstone.

Feiman-Nemser, S. (2001). From preparation to practice: Designing a continuum to strengthen and sustain teaching. Teachers College Record, 103(6), 1013-1055. http://dx.doi.org/10.1111/0161-4681.00141

Glaser, B.G., \& Strauss, A.L. (1967). The discovery of grounded theory: Strategies for qualitative research. Hawthorne, NY: Aldine De Gruyter.

Hull, G., \& Schultz, K. (2001). Literacy and learning out of school: A review of theory and research. Review of Educational Research, 71, 575-611. http://dx.doi.org/10.3102/00346543071004575

Larson, J., \& Marsh, J. (2005). Making literacy real: Theories and practices for learning and teaching. Thousand Oaks, CA: Sage Publications.

National Governors Association Center for Best Practices \& Council of Chief State School Officers. (2010). Common Core State Standards for English language arts and literacy in history/social studies, science, and technical subjects. Washington, DC: Authors.

Schon, D.A. (1984). The reflective practitioner: How professionals think in action. New York: Basic Books.

Silverman, D. (2001). Interpreting qualitative data: Methods for analysing talk, text and interaction (2nd ed.). Thousand Oaks, CA: Sage Publications.

Street, B.V. (1995). Social literacies: Critical approaches to literacy development, ethnography, and education. New York: Longman Publishing, Inc. 